\title{
Participatory Policy Model in Urban Forest Management Case Study At Forest Park Dr. Muhammad Hatta City Of Padang
}

\author{
Adil Mubarak ${ }^{1}$, Karjuni Dt. Ma'ni ${ }^{2}$, Aldri Frinaldi ${ }^{3}$ \\ \{adilmubarak@fis.unp.ac.id ${ }^{1}$,dtmaani@yahoo.com ${ }^{2}$, alfrinaldi@gmail.com ${ }^{3}$ \} \\ Department of Public Administration, Universitas Negeri Padang, Padang, Indonesia ${ }^{1,2,3}$
}

\begin{abstract}
Eleven types of policies have been established as the basis for the management of Dr. Muhammad Hatta (Tahura Bung Hatta) Padang City, an urban forest that functions as a conservation forest, educational forest and recreational forest, has not developed according to the plans formulated in these various policies. Previous research shows that the problem lies in the formulation and implementation model of policies that prioritize only institutional initiation (institutional model). This research aims to develop a policy model in developing the management of Bung Hatta's Tahura. This study uses a qualitative research method with a descriptive approach, collecting data by conducting in-depth interviews, focus group discussions, observation, and documentation. Determination of research informants was carried out purposively by using the snowball sampling technique. The results of this study have developed a participatory policy model, namely a policy that involves all stakeholders at the stages of policy formulation and implementation.
\end{abstract}

Keywords: Urban Forest Management; Policy Model; Participatory Policy.

\section{Introduction}

This article is the result of second-year research on urban forest management models in Dr. Muhammad Hatta (Tahura Bung Hatta) Padang City. Tahura Bung Hatta is a public domain whose management is currently handed over to the Padang City government through the Padang City Agriculture Service [1]. The Bung Hatta Grand Forest Park area is an area of primary forest nature reserve whose function is to conserve germplasm, protect natural resources, education and research, fostering a love for nature, as well as a place of recreation. The total area of the Protected Forest is $\pm 70,000 \mathrm{Ha}$, with a utilization area of $\pm 240 \mathrm{Ha}$., Which is in the Paddy Field area, $\pm 23 \mathrm{Km}$ to the east of Padang City, or on the Padang-Solok route, with a travel time of 25 minutes by motorized vehicle from Padang city. Geographically, Hatta Raya Forest Park is located between $100^{\circ} 17^{\prime}-100^{\circ} 42^{\prime}$ East Longitude and $0^{\circ} 32^{\prime}-1^{\circ} 5$ 'South Latitude.

Management of the Bung Hatta Tahura by the Padang City Agriculture Office is currently carried out by the Bung Hatta Tahura technical service unit (UPTD) based on various policies that have been established by institutions related to the forest management sector in Indonesia. These policies are [2] : 
Table 1. Policies Related to the Management of Great Forest Parks Dr. Muhammad Hatta Prov. West Sumatra, Padang City

\begin{tabular}{|c|c|c|c|}
\hline No & Title and Number & Year & About \\
\hline 1 & Constitution No. 41 & 1999 & Forestry \\
\hline 2 & Government regulations No. 28 & 2011 & $\begin{array}{l}\text { Management of Nature Reserves } \\
\text { and Nature Conservation Areas }\end{array}$ \\
\hline 3 & $\begin{array}{l}\text { Ministerial regulation LHK No. } \\
\text { P.76/Menlhk-Setjen/2015 }\end{array}$ & 2015 & $\begin{array}{l}\text { Zone Criteria for Management of } \\
\text { National parks and the } \\
\text { Management Block of Nature } \\
\text { Reserves, Wildlife Reserves. }\end{array}$ \\
\hline 4 & $\begin{array}{l}\text { Minister of Forestry Regulations } \\
\text { No. P.10/Menhut-II }\end{array}$ & 2009 & $\begin{array}{l}\text { Guidelines for the Preparation of a } \\
\text { Forest Forest Management Plan }\end{array}$ \\
\hline 5 & $\begin{array}{l}\text { Decree of the Director-General of } \\
\text { Forest Protection and Nature } \\
\text { Conservation No. SK. 76/IV- } \\
\text { KKBHL/2015 }\end{array}$ & 2015 & $\begin{array}{l}\text { Register Number of Nature Reserve } \\
\text { Area, Nature Conservation Area, } \\
\text { and Buru Park }\end{array}$ \\
\hline 6 & $\begin{array}{l}\text { West Sumatra Governor } \\
\text { Regulation No. } 92\end{array}$ & 2012 & $\begin{array}{l}\text { Concerning West Sumatra } \\
\text { Provincial Forestry Plan 2012-2031 }\end{array}$ \\
\hline 7 & $\begin{array}{l}\text { Decree of the Director-General of } \\
\text { Forest Protection and Nature } \\
\text { Conservation No. 335/ IV- } \\
\text { KKBHL }\end{array}$ & 2013 & $\begin{array}{l}\text { Forest Park Management Permit } \\
\text { Recommendation Muhammad } \\
\text { Hatta }\end{array}$ \\
\hline 8 & $\begin{array}{l}\text { Padang Mayor Regulations No. } \\
68\end{array}$ & 2017 & $\begin{array}{l}\text { Establishment of UPTD Working } \\
\text { Group Organization and Procedure } \\
\text { at the Department of Agriculture }\end{array}$ \\
\hline 9 & The strategic plan & 2018 & $\begin{array}{l}\text { Bung Hatta Tahura Long-Term } \\
\text { Management Plan }\end{array}$ \\
\hline 10 & Document & 2018 & $\begin{array}{l}\text { Map of the Arrangement of the } \\
\text { Bung Hatta Tahura Block }\end{array}$ \\
\hline 11 & Document & 2018 & $\begin{array}{l}\text { Forest Park Design Site Dr. } \\
\text { Mohammad Hatta }\end{array}$ \\
\hline
\end{tabular}

Ideally, each policy contains objectives, hypotheses and legitimacy that have been formulated and has received support from various parties so that in the implementation stage all implementers can implement the policy effectively. However, this is not the case with the various policies above, the policies governing the governance of Bung Hatta's tahura have not succeeded in showing any changes to the development of the management of Bung Hatta's tahura in accordance with its function as a conservation forest, education forest and recreational forest.

Head of the West Sumatra Provincial Forestry Service, Mr. Yozarwardi U.P, S.Hut., M.Si in an interview session said that the management of Bung Hatta's Tahura had slowed down its development because its management policies had undergone various changes so that the implementer had difficulty executing the policy. He added that apart from the policy change factor, the slow progress of Bung Hatta's Tahura development was also caused by budget problems, he explained that the Padang City Agriculture Service had a very limited budget to explore forest potential or to realize ideal Tahura, he suggested that Tahura should be managed collaboratively which implemented by related agencies as previously done but not maximally. 
Public policy is a legal instrument for the government in formulating and implementing a program, the process of its formation is carried out with various approaches, if it refers to Law No. 12 of 2011 concerning the formation of statutory regulations, there are at least several stages in policymaking, namely planning, drafting, discussing, ratifying or enacting and promulgating. In the formation of policies, it must also prioritize the aspirations of the community, and more importantly, in every stage, it must involve components of society to produce a policy that has public value.

The policy for the management of the Bung Hatta Tahura in a procedural manner has been established following the provisions of the law, however, the qualifications of the rules produced have not been able to be implemented effectively. The main reason is that almost all policies do not fully pay attention to the real conditions of the urban forest and the socio-cultural, economic, and environmental conditions of the people living in the forest. The policies made are relatively uniform which are used by managers or local governments throughout Indonesia which have urban forests. Policies that come down from the top (top-down model) tend to be difficult to adapt to real conditions at the local level where the policies will be implemented. Thus, in the first year of research, it was concluded that the management policy model for Bung Hatta's Tahura in Padang City was identified using an institutional model, namely a policy that was formulated by prioritizing institutional interests and having a top-down character. For this reason, a breakthrough is needed in the formation of an effective Tahura management policy, which is participatory and prioritizes local wisdom conditions, involving related parties so that the resulting policy has public value and is easy to implement.

Based on the results of previous research, in this second year the research problem formulation is what alternative policy models can be developed and used to form an effective policy both in its formulation and in its implementation?

\section{Methodology}

This study uses qualitative research methods with descriptive approaches [3]. The location of the research was Padang City in Padang City Agriculture Bureau and Great Forest Park. Dr. Muhammad Hatta City of Padang. The researcher collected data by conducting in-depth interviews, observation, and documentation techniques. The determination of research informants was carried out purposively using snowball sampling techniques.

The researcher also collected data through documentation techniques, namely by collecting several archives of communication activities, regulations, and policies produced by the government as well as decisions issued. The data analysis method used was a triangulation method that aimed to validate the data found in research or based on theoretical studies. the technique of selecting informants in this study was carried out using a purposive method.

\section{Finding and Discussion}

The main problem of forest management in Indonesia, according to Ujud Tajahuddin [4] is the policy of handing over authority which stipulates that forests belong to the State, so that forest management policy made by the government tend to be top-down and pay less attention to the involvement of other stakeholders. One type of forest whose management is regulated by the state is the Grand Forest Park (Tahura) which has the function of conservation forest, educational forest, and recreational forest. Functionally, Tahura is regulated uniformly through 
a model of institutional policies. The hierarchical management of Tahura policies makes room for managers to innovate freely. The policies that flow from above can be seen in the image below.

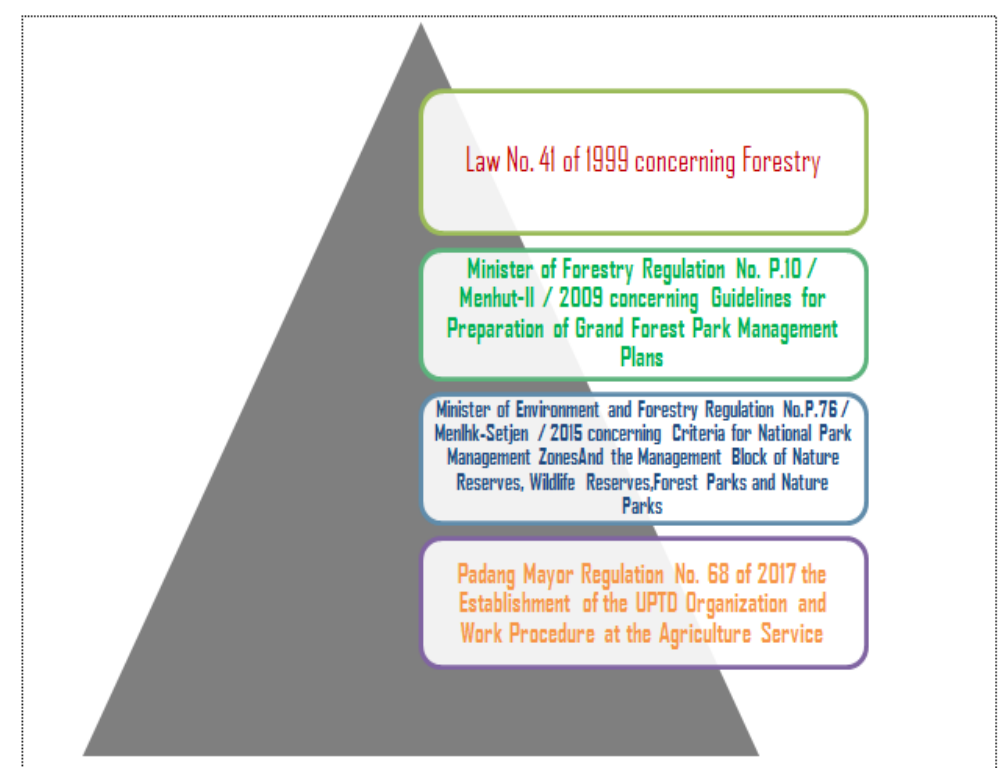

Fig. 1. The hierarchy of Bung Hatta's Tahura management policies

Padang City Agriculture Office as the leading sector of Tahura management through UPTD Tahura Bung Hatta since 2017 has not been able to carry out the development of Tahura optimally following the proper function of Tahura. Secretary of the Padang City Agriculture Office, Mrs. Yoice Yuliani, conveyed that the management of Tahura as a conservation forest and at the same time as a recreational forest requires a lot of resources, with conditions like this the Office cannot carry out the development optimally, what can be done now is to maintain and maintain existing assets so They do not become a decreasing asset such as buildings in forest areas, rare plants that are used as objects of research by some groups, while recreational destinations that once existed are no longer functioning. 


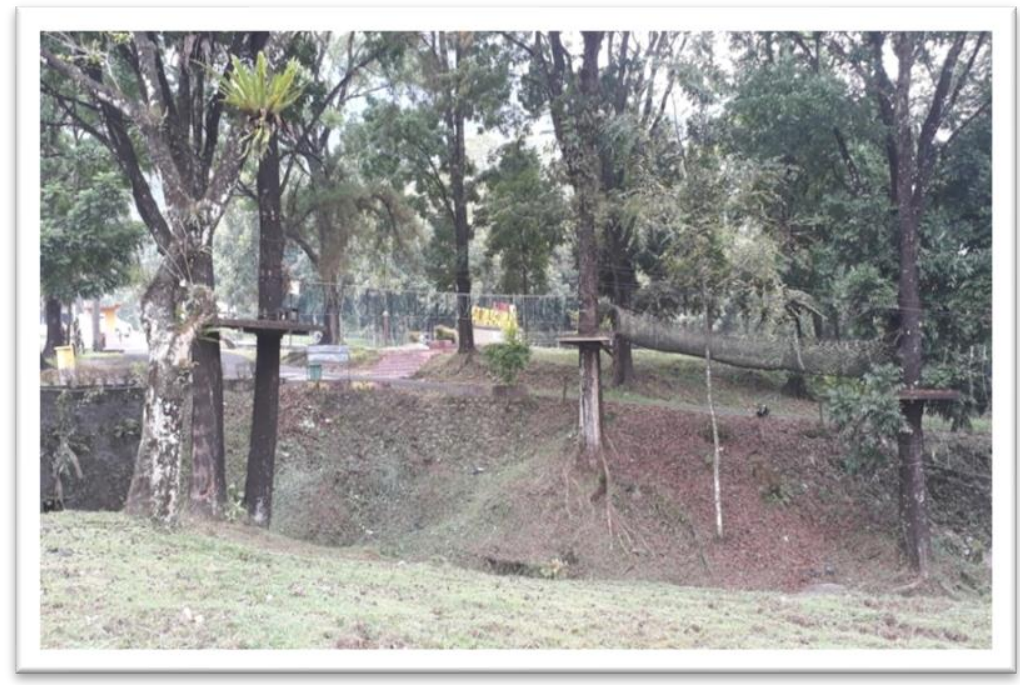

Fig. 2. Damaged tourist destination conditions

Mr. Hanibal Husein, Head of UPTD Tahura Bung Hatta also acknowledged that with the existing policies of the central government the UPTD had made efforts to develop some of these regulated zones, the UPTD collection zone had carried out maintenance and cooperation with related institutions, However, the utilization zone, which is the widest zone of the other zones, has yet to be utilized. Previously, this zone was used for tourism development but did not work properly. Based on the existing regulations in the utilization zone, the manager can cooperate with investors, but the government has not been able to invite investors to develop the Bung Hatta Tahura.

Head of the West Sumatra Forestry Service, Mr. Yozarwardi, said that Tahura Bung Hatta should be managed jointly, if you look at the function of the forest, the forest management must be carried out collaboratively between several cross-sectoral agencies, he hopes that Tahura management should be under the provincial government through the forestry service to get a portion of the budget. and other more optimal resources, the management can involve the tourism office, the agriculture office, the education office, and the people who have concerns and interests in the benefits of forests. It is necessary to have a level of participation in the line sector, especially the involvement of stakeholders in the development of Tahura, by creating policies that promote local wisdom and involve the community.

Based on the results of the first year's research on the Tahura management policy model and input from various parties, in the second study, an alternative policy model will be developed which is considered more effective. Weaknesses and various obstacles faced in the implementation of previous policies with institutional models are the difficulties of translating policy content by the implementor following the policy goals and objectives that have been formulated, then the weak involvement of related parties in policy making so that these parties do not have strong relationships In the development of Tahura, and other problems are the problem of inadequate budget resources, this research will formulate a policy model that tries to cover the weaknesses in the previous policy model, while the model offered is a participatory policy model. 
According to Suhirman [5], there are several developments in basic concepts and assumptions that form the basis for the widespread ideas and practices of citizen participation in the formation of public policies. First, participation is a political right inherent in citizens as well as other political rights. Because it is attached, this right is not lost when it mandates people to sit in government institutions. The mandate is partial, namely to place representatives to discuss and decide public affairs in formal state institutions. Meanwhile, political rights - as human rights - remain attached to each individual concerned. For this reason, it is the right of every citizen to protect the public space from state intervention to aggregate problems and various interests in the public space, to design a public agenda, and to continuously monitor representative institutions and government to work following the mandate given.

The forms of participation in the formation of policies have varying levels, in the management of Tahura, of course, all interested parties are demanded, especially those around the Tahura area and the general public as visitors to Tahura for traveling, doing research, or just doing other activities. The table below illustrates the form of stakeholder and community participation in the formation of Tahura management policies.

Tabel 2. Forms Of Public Participation In Policy

\begin{tabular}{|c|c|c|}
\hline Level & Participation & Example \\
\hline \multirow[t]{6}{*}{ high } & Have control & $\begin{array}{l}\text { Institutions, government, legislatures, NGOs encourage the } \\
\text { community to identify problems of objectives, aims, and key } \\
\text { conclusions. The institution has the willingness to help the } \\
\text { community in every step of the way in accomplishing its goals }\end{array}$ \\
\hline & Has delegated power & $\begin{array}{l}\text { Institutions, governments, legislatures, NGOs identify problems } \\
\text { and communicate to the community, define limitations and } \\
\text { make decisions that can be incorporated into an accepted plan }\end{array}$ \\
\hline & $\begin{array}{l}\text { Involvement in } \\
\text { planning }\end{array}$ & $\begin{array}{l}\text { Institutions, governments, legislatures, NGOs convey a } \\
\text { statutory plan and are open to accepting changes from affected } \\
\text { subjects, expecting the least change in plans and perhaps more. }\end{array}$ \\
\hline & Suggestion & $\begin{array}{l}\text { Institutions, government, legislatures, NGOs submit plans and } \\
\text { invite community responses. Plans are only prepared and } \\
\text { modified, if necessary }\end{array}$ \\
\hline & Be consulted & $\begin{array}{l}\text { Institutions, governments, legislatures, NGOs try to offer plans, } \\
\text { seek support to obtain acceptance or impose sanctions so that } \\
\text { administrative procurement is achieved }\end{array}$ \\
\hline & $\begin{array}{l}\text { Receive information / } \\
\text { socialization }\end{array}$ & $\begin{array}{l}\text { Institutions, governments, legislatures, NGOs make plans and } \\
\text { announce them, communities are mobilized to hear information. } \\
\text { The community gathered together to be expected. }\end{array}$ \\
\hline Low & None at all & The public doesn't know at all \\
\hline
\end{tabular}

In the arena of policy formation, especially at the policy formulation stage, participatory policies can be categorized if the position of the community is at a strong level. In the formulation, there are many actors involved, not only dominated by administrative agents but also the roles of other actors at each level where the policy will be implemented. At least apart from administrative agents in the formulation of participatory policies, there are actors from the legislative body, the judiciary, interest groups, non-government organizations (NGOs), political parties, community groups, and the community as individuals. In developing the participatory 
policy model for the management of Bung Hatta's Tahura, the actors who should be involved have been identified.

Participatory policies that involve all stakeholders must be comprehensively formulated through identifying the types of policies to be made and who will be involved in the formulation, identifying who are the target targets of the policies, both those that have a direct impact on the policy and those who are not directly affected by the policy. , identify the expectations that exist in society by conducting investigations, observing and even surveying the roots of policies that are made to have value and benefits for the public, and designing such a systematic pattern of policies so that they can be easily translated by the implementer and disseminated to the target group or the general public. If this process is carried out in an orderly manner, it is very clear that the participatory model is a way out to create sustainable Tahura governance that is in the interests of the community.

Apart from collaboration between related government agencies, embracing the community in forest management is a strategic step that must be taken by the government. Participation from civil society played by various elements of society will provide added value in various aspects, for example in research conducted by Prasetya Tunggul Damayanti (2011) explaining that the presence of the community in forest conservation has an impact on the low levels of illegal forest destruction activities, people actively become the spearhead in preserving the forest because the community feels the benefits both socially, environmentally and economically.[6]

To see the participatory policy model scheme in the management of Bung Hatta's Tahura, it can be described as shown below : 


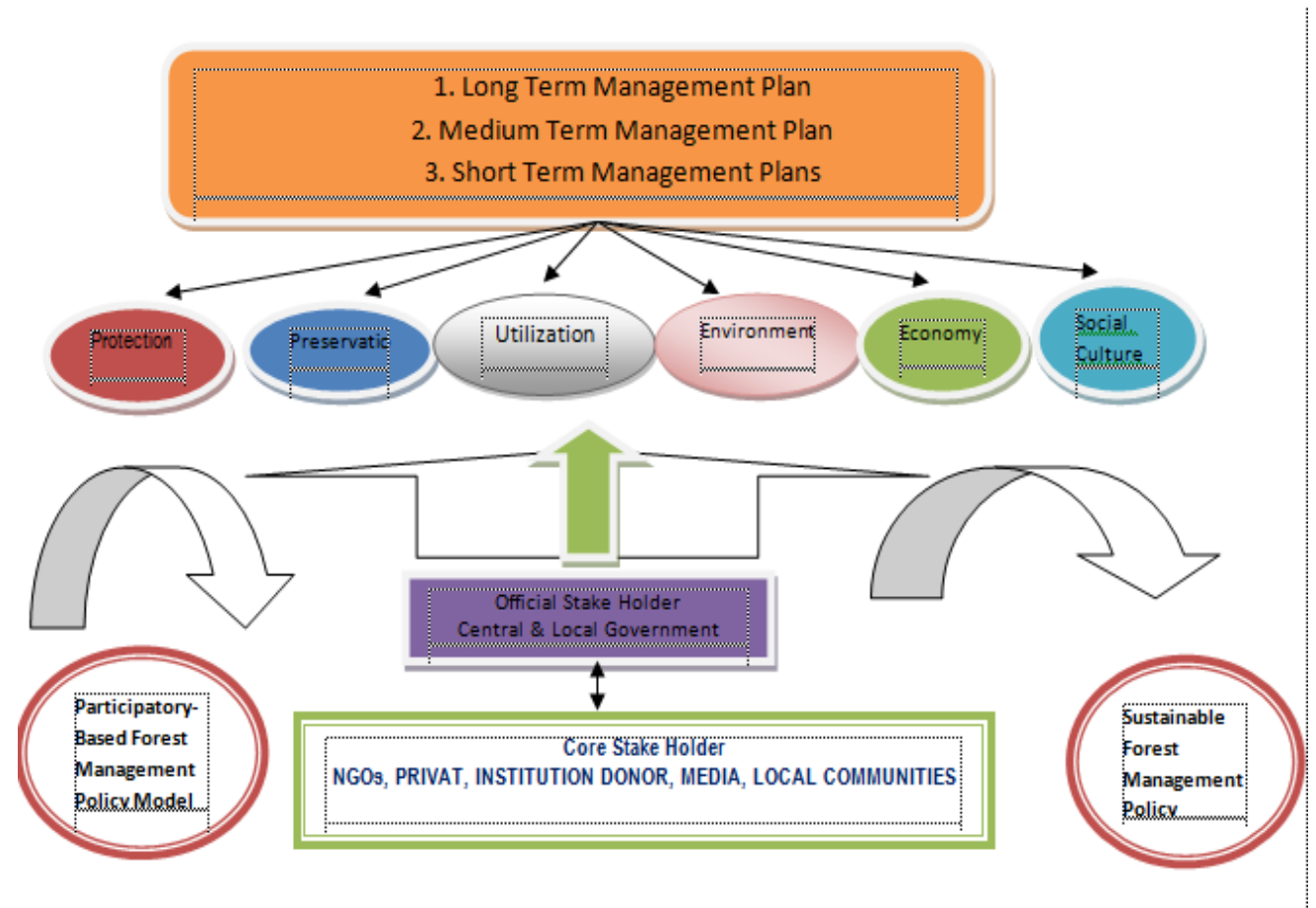

Fig. 3. Participatory policy model scheme for the management of the Bung Hatta Tahura in Padang City

2 main aspects must be considered in a participatory policy model, namely the formulation and implementation aspects of the policy. In the aspect of policy formulation for the management of the Bung Hatta Tahura in Padang City, 2 things must be considered, namely the formulation process which has been described in the previous explanation which starts from identifying the problem to determining the target group and the second is identifying the actors involved and the role of these actors. . As for the management of Tahura, in the formation of policies, actors who must be involved are based on the elaboration of the results of in-depth interviews with informants, namely (1) the Government, especially the local government, in this case, related agencies such as the forestry service, agriculture service, tourism service, education office, public works service, sub-district government, and sub-district government. (2) Legislative Institution, namely DPRD Padang City, (3) Interest groups played by community organizations / non-governmental organizations such as communities that love rare plants, (4) Communities which include visitors and communities around the Tahura area.

In the implementation aspect, participatory policies must also involve all parties to collaborate in implementing policies following the capacities and roles of each party [6]. For collaborative and participatory policy implementation in the management of Bung Hatta's Tahura, Padang City must be supported by 4 main factors [7], based on the results of in-depth interviews with several informants, these 4 things are (1) Communication factors, namely clear and consistent interaction between related parties. through channels that are designed effectively to avoid confusion of policy information, (2) Resource factors, wherein implementing the policy the resources must be measured, both human resources, budgetary resources, technological resources, method resources, and other resources. which supports the implementation of proper 
Tahura management, (3) the implementing factor, namely the commitment of the implementers to be total, creative, and innovative in carrying out their respective responsibilities, and the last are (4) structural factors, namely an effective organizational model, clear division of tasks and functions of each existing section.

\section{Conclusion}

The second-year research produced a policy model for the management of Bung Hatta's Tahura in the city of Padang after concluding that all this time the policies that were the legal basis for managing Tahura were tampered with and implemented with an institutional model, the model developed was a participatory policy model by relying on the collaboration of various interested parties starting from the government sector to the community. There are 2 important aspects in the participatory policy model, namely the aspect of policy formulation that must involve cross-sectoral actors, namely the government, legislature, interest groups, political parties, and society.

In the aspect of policy implementation, this model also requires the implementation of interactions consisting of balanced collaborative policy actors with an emphasis on 4 factors, namely communication factors, resource factors, implementing factors, and organizational structure factors.

\section{References}

[1] Parwoko Padang, Peraturan Wali Kota Padang Tentang Pembentukan Organisasi Dan Tata Kerja Unit Pelaksana Teknis Pada Dinas Pertanian. 2017.

[2] A. Mubarak, A. Karjuni Dt. Maani, and F. Aldri, "Urban Forest Management Policy Model (Case Study at Great Forest Park Dr. Muhammad Hatta, Padang City)," 2020.

[3] M. Lexy, J, Metodologi Penelitian Kualitatif, Edisi Revi. Bandung: PT. Remaja Rosdakarya, 2017.

[4] H. Hidayat, Pengelolaan Hutan Lestari. Partisipasi, Kolaborasi Dan Konflik. Jakarta: Yayasan Pustaka Obor Indonesia., 2015.

[5] Suhirman, Partisipasi Dalam Proses Pembuatan Kebijakan: Analisis Atas Kerangka Hukum Dan Praktik Pembuatan Kebijakan Ketenagakerjaan. Jakarta: PEG-USAID, 2003.

[6] P. T. Damayatanti, "UPAYA PELESTARIAN HUTAN MELALUI PENGELOLAAN SUMBERDAYA HUTAN BERSAMA MASYARAKAT," J. KOMUNITAS, vol. 3 (1), pp. 2011, [0-82, [Online]. Available: https://journal.unnes.ac.id/nju/index.php/komunitas/article/viewFile/2296/2349.

[7] A. Mubarak and N. E. Putri, "Implementation of Environmental Protection and Management Policies in Padang Panjang City," 2020.

[8] K. Solahuddin, Model Dan Aktor Dalam Proses Kebijakan Publik. Yogyakarta: Gava Media, 2010. 